\title{
POTENSI PEMBUATAN PRODUK KEMASAN RAMAH LINGKUNGAN STUDI KASUS KOTA BANDUNG
}

\author{
oleh: pratiwi Kusumo Wardhani
}

\section{ABSTRAK}

Limbah adalah isu didalam kehidupan kita. Limbah sintetik, terlebih lagi kemasan plastik dari industri makanan dan minuman adalah penyebab paling umum dari permasalahan Imbah. Jika sebelumnya kemasan makanan menggunakan material alami, sekarang ini, karena penggunaan besar-besaran di industri makanan, kemasan makanan beralih menggunakan material sintetis. Meskipun penggunaan kertas telah diperkenalkan untuk menggantikan penggunaan plastik, para pelaku industri masih tetap memilih menggunakan plastik dibandingkan material alami, karena plastik lebih baik dalam menjaga higienitas makanan dan juga lebih murah. Penelitian ini mencari cara untuk mengurangi limbah plastik dan menciptakan metode alternatif dalam membuat dan mengimplementasikan kemasan makanan. Termasuk melakukan penelitian untuk material baru, metode kemasan alternatif dan imple mentasi desain baru dalam industri kemasan makanan. Studi kasus untuk penelitian ini adalah kota Bandung, karena kota ini terkenal dengan banyaknya limbah yang dihasilkan. Luaran penelitian ini dapat diaplikasikan untuk kota lain di Indonesia.

\section{ABSTRACT}

Waste has been delicate issues in our life. Synthetic waste, especially plastics packages from the food and beverage industries are the most common cause of pollution. If previously, food are packed using natural materials, these days because of rapid changes in food industry, food are packed using synthetic materials. Although the use of paper was introduced to replace plastics, yet because plastics is cheaper and more reliable in keeping the food fresh and hygienic than paper, industries are more keen in using plastics instead of natural materials.

This research investigates ways of reducing the waste through inventing new designs for packaging products. This includes researching new materials, alternative method of packaging and ways of implementing of new design in food industries. The case study for this research is in Bandung, as this city is notorious for producing excessive waste. The outcome of this research can be applied in other cities in Indonesia.

\section{LATAR BELAKANG}

\subsection{LATAR BELAKANG PERMASALAHAN}

Bandung sejak lama dikenal sebagai tempat yang memiliki suasana yang nyaman dari segi keramah tamahan penghuninya pun suasana lingkungannya yang sejuk. Hal ini menjadikan Bandung sebagai salah satu kota tujuan wisata. Keberadaan perguruan tinggi negeri dan banyak perguruan tinggi swasta di Bandung membuat kota ini juga dikenal sebagai salah satu kota pelajar di Indonesia. Ramainya kunjungan para pendatang, baik sebagai pendatang yang akan menetap sebagai pelajar, maupun pen- datang yang hanya ingin sekadar melancong, marak ditunjang oleh dibangunnya jalan tol antar wilayah Bandung, terutama jalur yang menghubungkan dengan ibu kota Jakarta, sehingga semakin memudahkan pengunjung memasuki Bandung. Dengan demikian kehidupan perekonomian pun semakin ramai.

Kondisi ini membuat tumbuhnya objek-objek kewisata-an penunjang lainnya. Para pelancong memerlukan makanan, pakaian, dan oleh-oleh yang akan dibawa sebagai buah tangan pulang. Maka secara bersamaan tumbuhlah jenis-jenis wisata lain 
seperti 'wisata kuliner', 'wisata belanja', dan mungkin akan tumbuh jenis-jenis wisata lainnya.

\subsection{IDENTIFIKASI MASALAH}

Kawasan wisata adalah sebagai salah satu mata rantai pendukung pemasaran hasil produksi suatu wilayah, termasuk obyek wisata itu sendiri. Adanya obyek-obyek wisata bersama dengan adanya produksi berbagai produk khas yang bersumber daya dari wilayah setempat, bersamaan seluruhnya akan saling menguntungkan secara umum, berinteraksi saling mendukung memberikan citra 'image' untuk suatu kawasan. Untuk menampilkan kesatuan objek wisata bersamaan dengan produk-produk sampirannya, maka semua objek seharusnya dikemas dengan konsep kemasan yang menyatukannya dalam suatu citra. Perdagangan oleh-oleh Bandung yang berupa berbagai produk termasuk penganan yang layak dijadikan cinderamata atau buah tangan dari pelancongan. Untuk itu perlu dibuat suatu bentuk tampilan yang mengemas berbagai produk membawakan citra Bandung atau Parahiangan.

Penelitian ini bertujuan menggali sumber daya alam dan perindustrian; besar maupun kecil, manufaktur atau kerajinan, yang dapat dimanfaatkan sebagai produsen kemasan berbagai jenis penganan cinderamata Bandung. Tema kemasan ini akan diarahkan untuk pula membantu menapis julukan "Bandung Lautan Sampah". Konsep material kemasan akan mencoba mengadaptasi konsep lingkungan hidup, menghindari sampah sintetik bahkan sampah toksik untuk mengantisipasi masalah pencemaran lingkungan.

\subsection{BATASAN MASALAH}

Ada beberapa macam unsur dalam menentukan produk dapat terjual dengan cepat diantaranya brand image, produk yang dijual, kemasan yang baik. Kemasan adalah salah satu unsur terpenting dalam perkembangan perdagangan berbagai produk, sekaligus sebagai kunci pada keberhasilan strategi

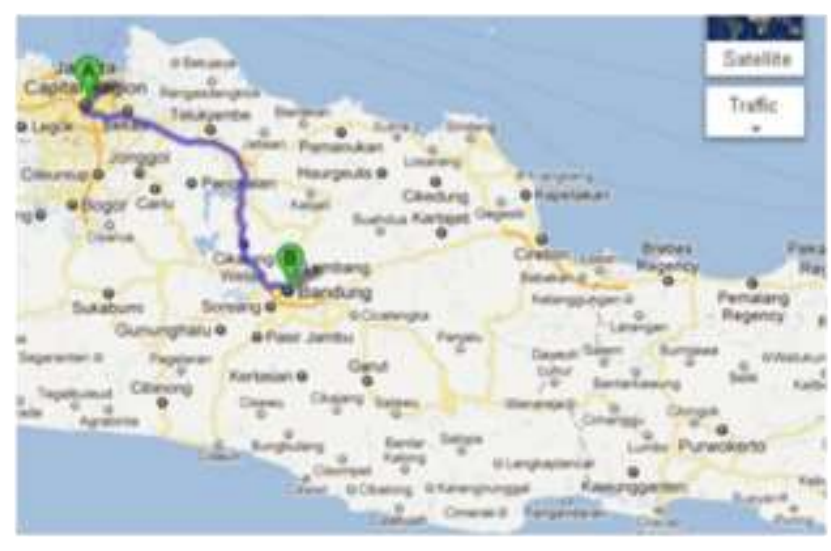

Gambar 1

Wilayah Bandung dikelilingi oleh Kabupaten-kabupaten

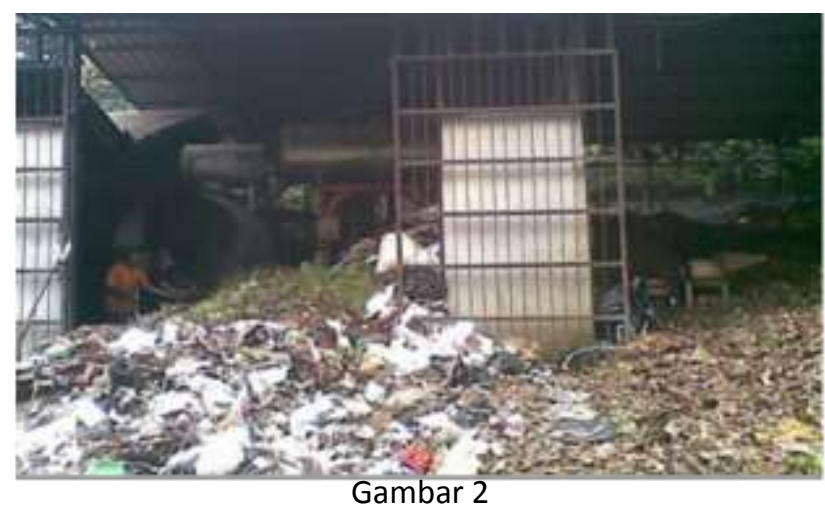

Sampah di jalan Ganesha, Bandung

penjualan produk. Konsumen seketika akan tertarik pada tampilan kemasan, dan terpengaruh untuk menempatkan posisi produk pada suatu tingkatan citra produk. Berbagai kategori produk seringkali dengan sangat mudah dapat tertangkap melalui karakter bentuk kemasannya. Terlebih dahulu tentunya yang akan dilakukan adalah pendataan mengenai berbagai jenis produk yang ada. Beberapa produk sudah memiliki citranya. Seperti misalnya kotak susu murni memiliki ukuran standar yang pasti, beserta tampilan grafis pada kemasannya, secara langsung dapat menginformasikan apa isi kemasan tersebut. Di sisi lain, bendabenda eksklusif, seperti perhiasan atau parfume, dapat mengambil bentuk yang tidak lazim demi menjadi penarik minat, eye catching.

Bahan kertas karton adalah bahan yang sudah lazim digunakan sebagai pengemas. Bahan ini digunakan karena alasan harga bahan yang relatif tidak mahal, mudah didapat, juga mudah untuk diproses dan diproduksi. Setelah penggunaannya, bahan tersebut mudah untuk didaur ulang. Teknik pencetakan sederhana pun dapat dengan mudah dilakukan pada bahan ini.

Namun berbagai wilayah di permukaan bumi ini pun memiliki material hasil bumi yang dapat dimanfaatkan sebagai material kemasan. Berbagai produk di Bandung terlihat menggunakan material bambu atau daun pisang sebagai kemasan penganan.

Banyak material alam yang digunakan sengaja diambil dari tumbuhannya untuk digunakan sebagai material pengemas penganan, seperti daun pohon pisang. Sebagian di antaranya ada penganan yang dikemas menggunakan material limbah hasil bumi, yang setelah diolah sedemikian rupa, maka bahan tersebut layak digunakan, seperti penganan dari Cililin yang dikemas dengan lembaran klobot jagung, tape ketan dari Cianjur yang dibungkus dengan daun dari pohon ketumbar, kue moci yang diwadahi di dalam keranjang bambu muda, dan sebagainya.

Wilayah Jawa Barat mempunyai hasil bumi yang 
berlimpah, termasuk sisa material dari produk lain (daging batang bambu, daun bambu, klobot jagung, daun pisang, dsb.) hendaknya dimanfaatkan sebagai beberapa sumber yang dapat memberikan nilai guna sebagai penambah peningkatan taraf hidup masyarakat di sekitar pinggiran kota sebagai penyedia jajaan produk di pusat-pusat wisata. Dengan pengolahan bahan baku yang bernilai relatif rendah, berarti pengurangan biaya dasar produk. Dan berarti pula peluang untuk pengolahan yang sangat optimal, sehingga produk jadi itu nantinya akan mempunyai nilai jual yang betul-betul efektif.

Di samping ketersediaan material, banyak masyarakat di wilayah seputar Jawa Barat adalah masyarakat yang memiliki keterampilan sebagai pengrajin. Masyarakat di Tasik memiliki kemahiran menganyam dan menenun. Masyarakat di Purwakarta dan Garut memiliki kemahiran menggerabah dengan kekhasan produk yang berbeda. Di beberapa tempat yang tersebar terdapat bengkel-bengkel mebel kayu yang membuat furnitur bergaya kuno. Dan beberapa tempat berkelompok terdapat unit-unit penyablon pakaian dan produkproduk kain.

Dengan demikian, berbagai kekayaan baik berupa material maupun kekayaan keterampilan yang telah disebutkan di atas, merupakan modal yang sangat berharga untuk digali dan dimanfaatkan dengan sungguh-sunguh sebagai media pendukung untuk menambah pendapatan wilayah untuk menunjang Jawa Barat sebagai daerah tujuan wisata. Penggabungan antara keterampilan pengrajin dan ketersediaan material di atas akan dapat terjalin dalam

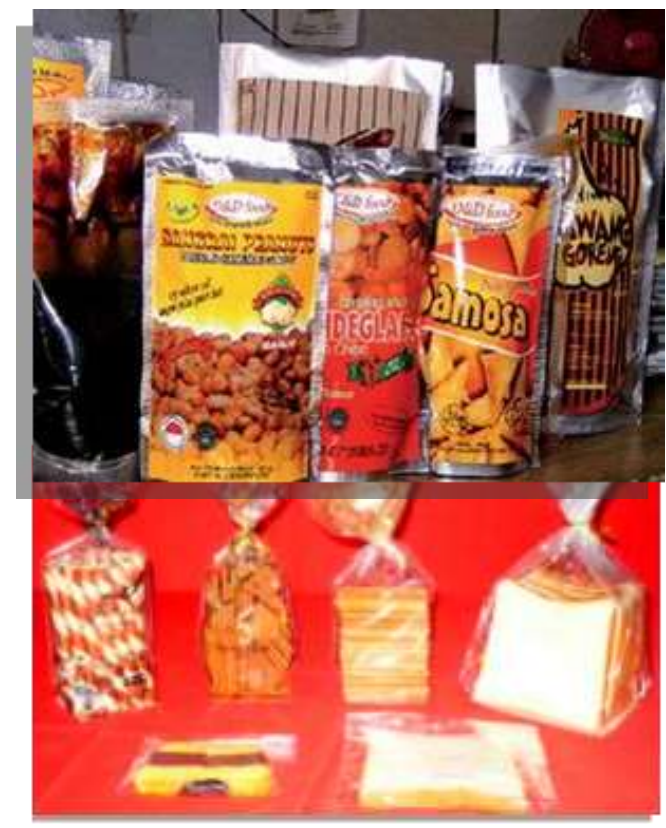

Gambar 3

Beberapa jenis kemasan yang sudah dapat menampakkan citra produk yang terdapat di dalamnya dan kita tidak mengetahui asal daerah yang memproduksi kemasan tersebut. bentuk produk-produk yang didesain sesuai peruntukannya.

\subsection{TUJUAN PENELITIAN}

1. Turut serta berperan aktif dalam mensikapi situasi nasional maupun internasional atas pencemaran lingkungan oleh berbagai limbah sintetis. Dan usaha ini pun harus mulai dilakukan sejak dari kalangan perindustrian kecil,

2. Mengupayakan menemukan suatu material kemasan baru yang ramah lingkungan yang dapat ditawarkan kepada seluruh lapisan terkait pada usaha yang menggunakan material kemasan,

3. Mengeluarkan suatu kebijakan baru mengenai penggunaan material kemasan yang ramah lingkungan, yang diberlakukan bagi semua lapisan terkait pada usaha yang menggunakan material kemasan,

4. Menggali desain kemasan yang bercitra khas untuk produk-produk cinderamata Jawa Barat,

5. Meningkatkan potensi produsen berbagai produk cinderamata atau oleh-oleh Bandung,

6. Mengintegrasikan kebutuhan akan kemasan yang dapat memberikan citra khusus, sekaligus memberdayakan sumber-sumber daya yang tersedia di wilayah Jawa Barat.

\subsection{SIGNIFIKANSI PENELITIAN}

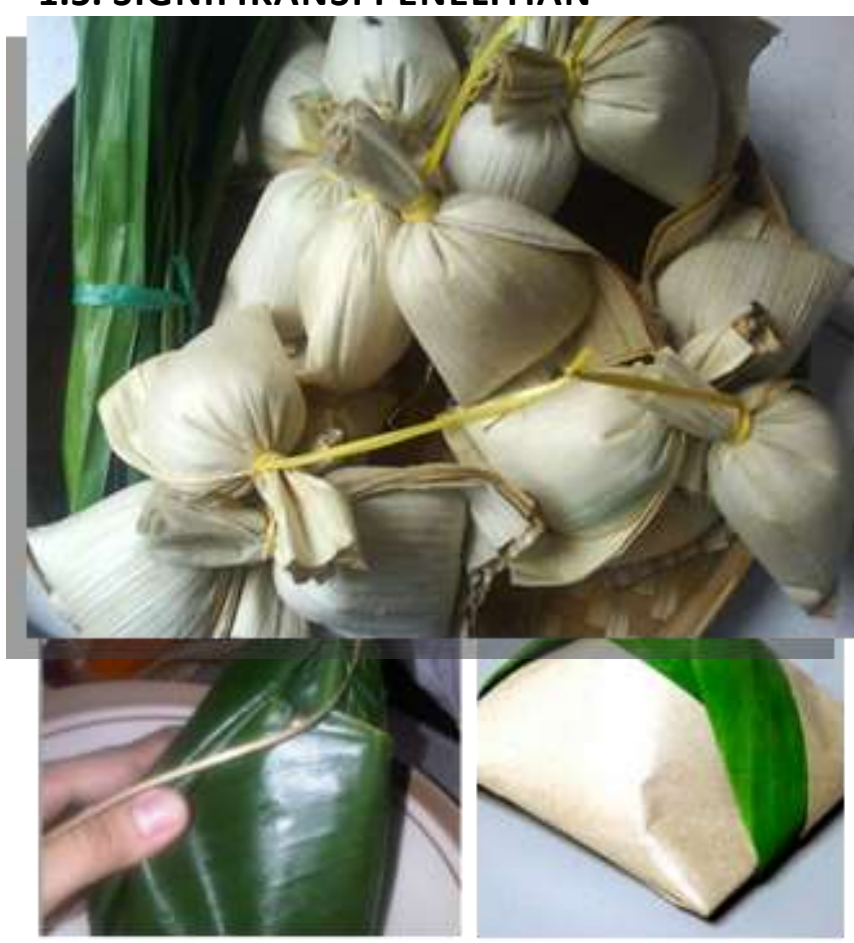

Gambar 4

Beberapa produk penganan matang maupun mentah yang dikemas mengguna kan daun pisang 
yang selama ini terbuang, atau bernilai jual sangat rendah, dapat membantu memberikan penghasilan tambahan bagi masyarakat di sekitar kawasan itu,

2. Membukakan peluang kerja lain bagi sumber daya pengrajin yang belum termanfaatkan waktu dan daya upayanya secara optimal; membantu membukakan wilayah garapan usaha baru untuk meningkatkan kesejahteraan masyarakat setempat,

3. serta turut memberikan pengayaan atas citra Bandung melalui peningkatan kualitas tampilan (visual) kemasan produk menjadi bernilai jual tinggi, dengan pertimbangan untuk menaikkan tingkat pendapatan dan taraf hidup masyarakat setempat,

4. Meningkatkan jumlah pengunjung; 'wisman' ataupun 'wisnu' ke obyek-obyek wisata di kawasan ini dengan cara meningkatkan kualitas berbagai aspek yang saling berkaitan di sekitarnya.

\section{STUDI PENDUKUNG}

\subsection{KAJIAN UMUM MENGENAI LIMBAH SAMPAH}

Pengertian Limbah atau sampah yaitu limbah atau kotoran yang dihasilkan karena pembuangan sampah atau zat kimia dari pabrik-pabrik. Limbah atau sampah juga merupakan suatu bahan yang tidak berarti dan tidak berharga, tapi kita tidak mengetahui bahwa limbah juga bisa menjadi sesuatu yang berguna dan bermanfaat jika diproses secara baik dan benar. Limbah atau sampah juga bisa berarti sesuatu yang tidak berguna dan dibuang oleh kebanyakan orang, mereka menganggapnya sebagai sesuatu yang tidak berguna dan jika dibiarkan terlalu lama akan menyebabkan penyakit padahal dengan pengolahan sampah secara benar bisa menjadikan sampah ini menjadi benda ekonomis.

\subsubsection{MASALAH SAMPAH DI KOTA BAND- UNG}

Salah satu kota di Indonesia yang memiliki masalah paling serius dengan sampah adalah kota Bandung. Berbeda dengan satu abad silam yang menempatkan kota Bandung sebagai Paris van Java yang sejuk dan nyaman, kini selain diliputi oleh persoalan kemacetan lalu lintas di seluruh kota yang parah kota ini dililit masalah sampah. Produksi sampah dari warga kota terus menumpuh hingga 550.000 meter kubik yang tidak terangkut karena warga rata-rata menghasilkan sampah sekitar 7.500 meter kubik per hari. Praktis, tidak ada satu pun ruang publik yang terlepas dari sampah.

Masalah pengangkutannya menjadi persoalan tersendiri. Masalah sampah di Bandung bahkan sempat mengakibatkan presiden SBY gusar. Ketika mengikuti lomba maraton di lapangan Tegalega, awal tahun 2006, SBY bersama rombongan menteri benar-benar ikut merasakan betapa rumitnya masalah sampah di kota ini. SBY bahkan sempat menyampaikan ultimatum kepada Walikota Dada Rosada. Selain mengutus Menteri Negara Lingkungan Hidup untuk menangani sampah secara terpadu, dia mengultimatum walikota agar dalam kunjungan selanjutnya pada bulan Juni 2006, sampah di Bandung sudah dapat ditangani. Tetapi persoalan sampah di Bandung memang tidak sederhana. Warga sudah telanjur memiliki perilaku yang skeptis terkait sampah. Tidak ada insentif apapun untuk mengurangi produksi sampah. Kecuali itu, penanganan sampah sejauh ini selalu menggunakan pendekatan berupa open dumping, sampah dikumpulkan ke TPS (Tempat Pembuangan Sementara) untuk kemudian ditumpuk hingga hancur sendiri di TPA (Tempat Pembuangan Akhir). Masalahnya adalah bahwa pendekatan penanganan dengan cara seperti ini sudah tidak memadai lagi dengan adanya volume sampah yang dari tahun ke tahun terus meningkat. Prediksi kasar menunjukkan bahwa dengan cara penanganan seperti ini, jika seluruh kawasan Bandung Raya (kota Bandung, Kabupaten Bandung, kota Administratif Cimahi, Kabupaten Garut, Kabupaten Sumedang) memproduksi sampah, total volumenya mencapai 4,5 juta ton kubik per hari. Dengan menggunakan cara open dumping, diperkirakan bahwa dalam waktu 25 tahun diperlukan 100 hektar tanah sebagai lokasi TPA. (http://kumoro.staff.ugm.ac.id/file_artikel/ Kasus $\% 207, \% 20$ Penang anan $\% 20$ Sampah $\% 20$ di $\% 20$ kota $\% 20$ Bandung.pdf).

\subsubsection{JeniS-JeniS SaMpah}

Berdasarkan cara pengelolaan dan pemanfaatannya, jenis sampah secara umum menurut dinas Pekerjaan Umum (1986) dapat dibagi menjadi 3 jenis yaitu:

1) sampah basah

Yaitu sampah organik yang mempunya sifat membusuk jika dibiarkan dalam keadaan basah, yang termasuk dalam sampah ini adalah sisa makanan, sayuran, buah-buahan, dedaunan, dsb.

2) sampah kering

Yaitu sampah yang terdiri atas bahan anorganik yang sebagian besar sulit untuk membusuk, sampah ini terbagi menjadi 2 jenis yaitu :

a) logam, contoh : kaleng, pipa besi tua, mur, baut, seng, dan segala jenis logam yang sudah usang. 
b) non logam.

3) sampah lembut

Yaitu sampah susunannya terdiri dari partikelpartikel kecil dan memiliki sifat mudah berterbangan serta membahayakan atau menggangu pernafasan dan mata. sampah tersebut terdiri atas:

a) Debu, yaitu parkel-partikel kecil yang berasal dari proses mekanis, misalnya serbuk dari pengergajian kayu, debu asbes.

b) Abu, yaitu partikel-partikel yang berasal dari proses pembakaran, misalnya abu sekam, abu dari hasil pembakaran sampah.

\subsubsection{KONSEP “ $3 R$ ”}

1) Mengurangi Bahan Timbunan Sampah (Reduce) Mengurangi bahan timbunan sampah, dapat berarti membiasakan hidup dengan penuh ketelitian, dan cermat sehingga sampah yang dihasilkan di tekan seminimal mugkin.

2) Memakai kembali (reuse)

Menggunakan kembali mengandung arti memakai item yang sama lebih dari skali, lebih disarankan. konsep memakai kembali (reuse) ini dapat menghemat energi dan sumber daya yang boleh jadi digunakan untuk membuat produk baru.

3) Daur ulang (recycle)

Mendaur ulang dapat berarti mengembalikan sampah ke pabrik sehingga dapat dignakan kembali sebagai bahan baku untuk membuat produk yang sama atau lainnya.

\subsection{KAJIAN UMUM MENGENAI KERTAS BEKAS}

\subsubsection{KARAKTER KERTAS BEKAS}

Beberapa jenis kertas bekas yang bisa didaur ulang. Namun pendauran ulang kertas hanya bisa dilakukan maksimal 4 - 6 kali, mengingat seratserat kertas akan semakin pendek setelah diproses sehingga memengaruhi kekuatan dan ikatan serat dalam kertas. Kertas yang bisa didaur ulang sangat beragam, namun dikelompokkan dalam tiga kategori diantaranya:

1. kertas buangan pabrik kertas,

2. kertas limbah sebelum digunakan konsumen,

3. kertas yang telah digunakan konsumen.

\subsubsection{JENIS KERTAS BEKAS}

Jenis kertas sangat beragam, mulai dari kertas bergelombang ( dus), kertas bekas koran, kertas bekas majalah, kertas bekas buku telepon, dan kertas be- kas kantor/rumah tangga.Pengolahan kertas daur ulang bisa dengan cara sangat sederhana, yaitu kertas hanya diubah bentuknya tanpa perlakuan fisika dan kimia. Misalnya kertas digunakan untuk dekorasi. Kertas diremas lalu bentuk lipatan-lipatannya dibentuk sesuai selera.Pengolahan kertas secara fisika dan kimia adalah mengolah kertas menjadi bubur kembali, lalu dicetak sesuai dengan keperluannya, baik tipis ataupun tebal. Kertas yang dibuat ubur ini yang hanya bisa didaur ulang hingga 4 - 6 kali, karena serat-serat kertas akan terpotong oleh perlakuan fisika (dihancurkan).

\subsubsection{PENGOLAHAN KERTAS BEKAS}

Di Indonesia, penggunaan kertas daur ulang untuk bahan baku industri kertas telah banyak dilakukan. bahan baku yang paling banyak di gunakan adalah diperoleh dari kertas bekas kosong, majalah, dan kertas tulis.

Produk kertas daur ulang berupa jenis kertas seperti kertas kemasan atau kertas untuk industri, kertas cetak dan kertas tulis, tissue dan cetakan untuk media massa. dalam jumlah terbatas, kertas daur ulang dapat juga digunakan untuk media tanaman isolasi, box, produk kertas cetak (wadah telur, karton, baki makanan, dan pot tanaman).

Hasil penelitian sebelumnya menunjukkan, kertas daur ulang ini memiliki beberapa keterbatasan produk yang dibuat dari proses ini tidak dapat digunakan untuk kemasan bahan panan, karena kualitas kertasnya menurun dan dapat mudah terkontaminasi.

Khusus untuk daur ulang kertas koran, diperlukan beberapa tambahan proses kimiawi untuk menghilangkan tinta yang ada pada kertas (deingking process). Proses ini menggunakan sabun untuk menghilangkan tinta. Tinta tersebut masih dapat dimanfaatkan untuk kondisi tanah (soil conditioner), kemudian untuk membuat kertas daur ulang yang baik dan dapat digunakan kembali sebagai bahan pembuat koran, diperlukan modifikasi campuran kertas yang terdiri dari atas campuran kertas koran bekas, majalah dan bubur kertas yang asli (virgin pulp) dari bahan baku awal.

\subsection{KEMASAN}

\subsubsection{KEMASAN FLEXIBLE}

Kemas fleksibel adalah suatu bentuk kemasan yang bersifat fleksibel yang dibentuk dari aluminium foil, film plastik, selopan, film plastik berlapis logam aluminium (metalized film) dan kertas dibuat satu lapis atau lebih dengan atau tanpa bahan thermoplastic maupun bahan perekat lainnya sebagai pengikat ataupun pelapis konstruksi kemasan dapat berbentuk lembaran, kantong, sachet 
maupun bentuk lainnya.

Pemasaran kemasan ini akhir-akhir ini menjadi popular untuk mengemas berbagai produk baik padat maupun cair. Dipakai sebagai pengganti kemasan rigid maupun kemas kaleng atas pertimbangan ekonomis kemudahan dalam handling.

Biasanya bahan yang digunakan sebagai bahan utama dalam pembuatan kemas flexible adalah antara lain film plastik, selopan, aluminium foil dan kertas. Untuk memenuhi fungsinya dengan baik film plastik dan aluminium foil dan kertas dalam berbagai kombinasi dibentuk sebagai multi layer dan diextrusion dengan resin plastik, polyethilen, polypropylene, eva, dan lain sebagainya, sehingga menjadi satu kesatuan ataupun dilaminasi dengan adhesive tertentu.

Kombinasi dari berbagai material tersebut, akan memberikan kemasan yang lebih sempurna dari prosuk tersebut. Dapat disimpulkan bahwa bahan yang digunakan adalah sebagai berikut :

- Bahan Utama : film plastik, selopan, aluminium foil, metalized film,kertas dan sebagainya.

- Bahan Pengikat : perekat/adhesive dan extrusion dari bahan Thermoplastic

- Bahan Penolong : antara lain tinta dan solven

\subsubsection{JENIS DAN BAHAN KEMASAN}

\section{A. KERTAS}

Ada berbagai macam jenis kertas yang dikenali, dengan sifat tertentu dan dengan aplikasi tertentu. Kertas dibagi dua dalam klasifikasi yang luas, ialah cultural papers atau fine paper dan industrial paper atau coarse papers. Cultural paper: antara lain printing paper, litho paper, artpaper dan lain-lain.

Industrial paper : antara lain kraft paper, manila paper, glassine paper, grease-proof paper dan lain-lain.

Untuk keperluan kemasan fleksibel, selain menggunakan kertas industri seperti kraft paper dan glassine paper juga digunakan cultural paper, seperti litho paper dan art paper. Kraft paper, karena sifatnya yang kuat, banyak digunakan dibidang kemasan fleksibel, terutama sebagai shopping bag.

Kertas kraft digunakan juga pada pembuat multi wall shipping bag, kertas yang banyak juga digunakan untuk kemasan fleksibel adalah glassine dan grease proof paper. Penampilan dan sifat yang khusus dari kertas ini, bukan karena penambahan aditif, tetapi karena sifat dari pulp yang dipakai.

\section{B. ALUMINIUM FOIL}

Aluminium foil menempati posisi yang penting dalam produk kemas fleksibel karena memiliki barriers yang memuaskan dan penampilan yang baik. Foil yang biasa digunakan dengan ketebalan antara 6 mikron sampai dengan 150 mikron baik soft temper maupun hard temper. Soft maupun hard temper, tergantung dari komposisi dari alloy dan treatment terhadap foil tersebut.

Umumnya untuk kepentingan kemas fleksibel foil yang digunakan tebalnya kurang dari 25 mikron. Namun demikian untuk keperluan tertentu dengan contoh yang lebih tebal aluminium foil yang soft temper akan mudah membentuk dead-fold, dan tidak mudah kembali, dan bisa dibentuk menurut keinginan. Foil adalah tak berbau, tak ada rasa, tak berbahaya dan hygienis, tak mudah membuat pertumbuhan bakteri dan jamur. Karena harganya yang cukup mahal, maka aplikasi dari aluminium foil sekarang ini banyak disaingi oleh metalized aluminium film. Coating yang sangat tipis dari aluminium, yang dilaksanakan di ruang vacuum, hasilnya adalah suatu produk yang ekonomis dan kadang-kadang fungsinya dapat menyaingi aluminium foil.

\section{METODELOGI PENELITIAN}

Dalam penelitian kali ini penulis menggunakan cara pendekatan kuantitatif dengan mengumpulkan data-data yang mendukung.

Dalam rangka mendapatkan data-data yang mendukung penelitian kali ini adalah dengan mengiventarisasi potensi berbagai sumber daya diantaranya;

1. Mencari sumber daya perindustrian kecil maupun menengah yang berhubungan dengan material kemasan.

2. Mencari sumber tenaga kerja - manusia; sebagai pengrajin, skill.

3. Menganalisa sumber daya alam - berbagai ma-

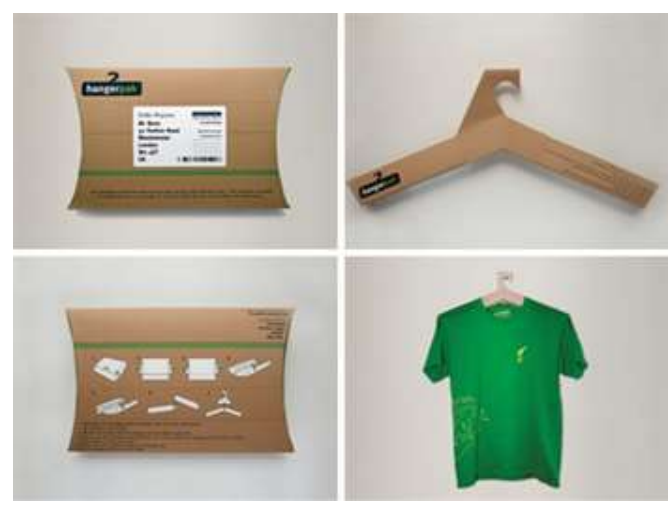

Gambar 5

Contoh produk pakaian sablon yang sudah dikemas secara khusus, memberikan bentuk Dan citra khas yang tidak mudah terlupakan

terial alam atau sisa bahan tak yang sebelum ini tak termanfaatkan.

4. Menganalisa potensi wilayah - potensi wisata dan khasanah budaya daerah sebagai potensi pasar. 


\section{POTENSI BERBAGAI SUMBER DAYA}

\subsection{SuMber daya penGraJin \& perin- DUSTRIAN}

Dengan adanya kelompok-kelompok pengrajin yang tersebar di wilayah Jawa Barat, dan kemampuan dasar masyarakat yang pada umumnya berketerampilan ke arah jenis kegiatan kerajinan Tasik, Cirebon, Cililin, dsb., maka berarti salah satu daya dukung untuk mewujudkan wilayah ini menjadi kota industri kecil kerajinan sudah ada.

Selain terdapat sebuah perindustrian yang terpaut pada Departemen Perindustrian \& Perdagangan (PT Kria Kertas Kemasan), yang selama ini menghasilkan produk-produk kemasan, telah menyatakan keinginannya membuat pengembangan atas berbagai jenis dan desain kemasan.

\subsection{SUMBER DAYA ALAM}

Banyaknya hasil bumi di kawasan ini memberikan peluang dan tantangan yang sangat luas untuk melakukan apapun, untuk mengambil manfaat yang diberikan alam, sebelum memutuskan untuk memilih bahan-bahan sintetis. Selain harga bahan yang semangkin melonjak, krisis pencemaran lingkungan yang semangkin meluas juga ke pelosokpelosok, hendaknya perlahan dicarikan alternatif pemecahannya. Meskipun dalam prosentase sangat kecil dibandingkan dengan pencemaran dunia yang sudah terlanjur melimpah. Dan Bandung sudah terlanjur dijuluki "Lautan Sampah".

\subsection{SuMber daya Wilayah-potenSi WISATA DAN KHASANAH BUDAYA DAERAH SEBAGAI POTENSI PASAR}

Menggali dan menemukan berbagai kekhususan citra yang terkandung pada berbagai aspek kehidupan di Bandung atau Jawa Barat, untuk kemudian dapat diangkat sebagai materi pencitraan Bandung untuk menyampaikan berbagai pesan visual, termasuk pesan-pesan komersial.

\subsection{TEKNOLOGI SEBAGAI SUMBER DAYA}

Penelitian ini dapat dilakukan kerja sama dengan institusi pendidikan yang berkaitan dengan teknologi lingkungan, seperti halnya ITB sebagai pusat pengambangan pengetahuan \& teknologi, sehingga tidak sulit untuk menggali dan menemukan berbagai material yang tepat yang diperlukan untuk menanggulangi sampah yang menjadi permasalahan lingkungan ini.

\subsubsection{MEMBUAT KLASIFIKASI SPESIFIK BER- BAGAI PRODUK CINDERAMATA}

Berikut adalah proses dalam rangka mengklarifi- kasi produk-produk cinderamata diantaranya yaitu:

1. Melihat Jenis produk (penganan, pakaian, ben da kerajinan bambu, kulit, kayu, alas kaki, dsb).

2. Melihat Karakter produk (material, dimensi).

3. Menghitung Ukuran persatuan potong, persatuan unit.

4. Mencoba bernagaimacam cara mengoperasikan, (cara kemas, cara distribusi).

\subsubsection{MEMBUAT SPESIFIKASI BAHAN PENGEMAS}

Berikut adalah proses dalam rangka membuat spesifikasi bahan pengeras, bahan pengeras bertujuan untuk memberikan daya tahan keawetan sebuah produk, agar lebih tahan lama. Proses tersebut dilakukan dengan mencoba satu persatu bahan yang akan digunakan Bahan yang pernah digunakan adalah lembaran daun, atau rautan, daging batang, atau material temuan baru. Jenis dan sifat struktur : berserat searah; relatif kuat, pembentukan lebih baik dilakukan sebelum atau sesudah bahan menjadi kering. Warna dan tekstur : warna-warna natural Berikut adalah hasil eksperimen dari lembar daun:

a) Bila kondisi kegunaan akan selalu kering, maka apakah mungkin untuk tidak digunakan bahan pengawet.

b) Bahan sebelum diolah, jenis pengolahan, sesudah diolah, serta target yang diharapkan dari bahan tersebut.

c) Menghindarkan penggunaan material toksik.

\section{KESIMPULAN DAN SARAN}

Dalam penelitian ini, penulis menyimpulkan bahwa salah satu solusi dari permasalahan sampah di kota Bandung yakni dengan mempergunakannya kembali sebagai kemasan sebuah produk.

Dengan proses mencari tahu dan menganalisa sampah yang ada di kota penghasil sampah terbanyak yakni Bandung dengan mempertimbangkan jenis material dan bahan yang tersedia, serta melihat potensi daerah penghasil sampah dan juga harus mempertimbangangkan potensi masyarakat daerah penghasil sampah. Dengan pertimbangan hal tersebut, potensi pemberdayaan sampah dapat menimbulkan inovasi baru yakni kemasan yang reusable.

Dengan adanya penelitian ini diharapkan dapat memberikan output berupa stimulus bagi desainerdesainer produk kemasan untuk menemukan cara agar masyarakat bersama-sama dengan pengusaha menyadari permasalahan pencemaran lingkungan yang diakibatkan oleh berbagai jenis penganan dan minuman, dan kemudian berupaya untuk menemukan suatu cara untuk mengurangi dampak bu- 
ruk sampah, yang kemudian dapat disepakati bersama penggunaan atau penerapannya.

Diharapkan dari penelitian selanjutnya dengan mencari, bereksperiman dan terus mengulik material sampah yang masih memungkinkan untuk di pergunakan lagi sebagai kemasan, atau menghasilkan suatu cara mengemas dengan desain kemasan baru, atau mungkin juga dengan menemukan suatu material baru sebagai bahan yang tidak akan menambah pencemaran lingkungan semakin memburuk, atau memberikan suatu kebijakan yang tidak menyulitkan penerapannya bagi semua pihak, dari segi proses produksi dan proses pengunaannya kelak dilapangan.

\section{DAFTAR PUSTAKA}

1. Ekajati, Edi S, Setiawan (2001) "Kemasan Tradisional Makanan Sunda" Bandung: Penerbit ITB

2. Kunto, H, (1986)"Semerbak Bunga di Bandung Raya", Bandung: PT Granesia

3. Lawson, Bryan. (2007) "Bagaimana cara berpikir desainer (How Designers Think)", Yogyakarta : Jalasutra

4. Norman, Donald. (2004) "Emotional Design", New York : Basic Books

5. Prahaland, C, K (2004) "The Fortune at The Bottom of The Piramid"mengentaskan kemiskinan sekaligus memperoleh laba", Jakarta: PT Intan Sejati Klaten

\section{BIOGRAFI PENULIS :}

Pratiwi Kusumo Wardani., M.Ds

Program Studi Desain Produk Universitas Pembangunan Jaya Jl. Boulevard Bintaro Sektor VII Bintaro Jaya, Tangerang Selatan 15224. 